\title{
Introductory Editorial Note to the Hungarian Report: The Pre-2010 Rule of Law Achievements and the Post-2010 Illiberal Turn
}

\author{
Anneli Albi
}

In the case of Hungary, from the perspective of constitutional law it is important to draw the attention of the reader to two distinct periods in the development of Hungarian constitutionalism: the period from the beginning of the post-communist constitutional reforms up to 2010, and the subsequent change of direction that was marked by the preparation and adoption of the new Fundamental Law in 2011. The post-2010 period has been described as one of 'illiberal constitutionalism', ${ }^{1}$ and has caused widespread concern amongst EU and Council of Europe institutions as well as other Member States. The Hungarian report to this volume focuses on the post-2010 period.

From the point of view of constitutional history, comparative European constitutional heritage and the questions explored in the project, it may be of interest for the readers to bear in mind that in the aftermath of the post-communist constitutional reforms, the Hungarian constitutional system was widely acclaimed in Europe for the particularly extensive safeguards for the rule of law and human dignity established by the Constitutional Court, as part of the concept of the 'invisible constitution'. As the former Chief Justice of the Hungarian Constitutional Court put it, constitutional review became 'a kind of symbol of the rule of law'. For example, in its early years, the Hungarian Constitutional Court struck down as unconstitutional roughly one out of three challenged laws, although a quieter tone was taken after $1998 .^{3}$ In particular, the Constitutional Court championed a robust and rigid approach to the principle of legal certainty and non-retroactivity as part of the doctrine of the rule of law and democracy. ${ }^{4}$ By way of what came to be widely

${ }^{1}$ Uitz 2014.

2 Sólyom 2002, p. 25, as cited in Prochazka 2002, p. 25.

${ }^{3}$ Scheppele 1999.

${ }^{4}$ Sadurski 2006, p. 14; Dupré 2003, p. 31.

\footnotetext{
A. Albi $(\square)$

University of Kent, Canterbury, UK

e-mail: A.Albi@kent.ac.uk
} 
regarded as a classic example, the so-called 'Bokros package' of statutes, which modified the benefits system as part of a vigorous economic rationalisation plan, was declared unconstitutional on the ground of breach of the principle of legal certainty: the very short time (two weeks) between the adoption of the statutes and their implementation did not leave individuals sufficient time to adjust to the new situation. ${ }^{5}$ In another landmark decision, a law aimed at lifting the statutes of limitations for politically motivated crimes committed under Communism was invalidated on the ground of non-retroactivity: it was found that such an ex post facto restoration of criminal liability would have amounted to an improper retroactivity of the law. ${ }^{6}$ Regarding judgments on human dignity, an extensive study of the relevant Hungarian judgments by Catherine Dupré revealed that whilst there was a general tendency for the judges to closely follow the German constitutional case law and reasoning, the Hungarian Constitutional Court selected those elements from the German doctrine that emphasised the individuality and autonomy of individuals, without importing the corresponding restrictions. ${ }^{7}$

This earlier case law was also at the origins of some of the questions in the Questionnaire of the present research project, and is taken into account in the identification of comparative European constitutional achievements in the protection of fundamental rights and rule of law safeguards in the Comparative Study that accompanies the national reports (as explained in the Introduction to this book). Thus this pre-2010 case law is worth bearing in mind, in addition to the material in the report that focuses on the post-2010 climate.

\section{References}

Dupré C. (2003) Importing the Law in Post-Communist Transitions. The Hungarian Constitutional Court and the Right to Human Dignity. Hart Publishing, Oxford.

Prochazka R. (2002) Mission Accomplished: On Founding Constitutional Adjudication in Central Europe. CEU Press, Budapest.

Sadurski W. (2006) Solange, Chapter 3: Constitutional Courts in Central Europe. EUI Law Working Paper 2006/40.

Scheppele K.L. (1999) The New Hungarian Constitutional Court. East European Constitutional Review 8:81-88.

Sólyom L. (2002) On the Co-operation of Constitutional Courts: Introduction to the 10th Conference of European Constitutional Courts. http://www.mkab.hu.

Uitz R (2014) Hungary. Paper presented at the ECSA-Austria workshop 'Member States' Constitutions and EU Integration', University of Maastricht, 5-6 June 2014, forthcoming in 2019 in Griller S., Claes M., Papadopoulou L., Puff R. (eds.) Member States' Constitutions and EU Integration. Hart, Oxford.

\footnotetext{
${ }^{5}$ Dupré 2003, p. 31.

${ }^{6}$ Sadurski 2006, p. 14.

${ }^{7}$ Dupré 2003, pp. 120 et seq., 122, 125-126.
} 
Open Access This chapter is licensed under the terms of the Creative Commons Attribution 4.0 International License (http://creativecommons.org/licenses/by/4.0/), which permits use, sharing, adaptation, distribution and reproduction in any medium or format, as long as you give appropriate credit to the original author(s) and the source, provide a link to the Creative Commons license and indicate if changes were made.

The images or other third party material in this chapter are included in the chapter's Creative Commons license, unless indicated otherwise in a credit line to the material. If material is not included in the chapter's Creative Commons license and your intended use is not permitted by statutory regulation or exceeds the permitted use, you will need to obtain permission directly from the copyright holder.

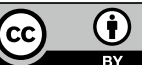

